\title{
INCIDENTE EM ANTARES E A VIOLÊNCIA INSTITUCIONAL NO BRASIL
}

\author{
POR \\ Maria da Glória Bordini \\ Universidade Federal do Rio Grande do Sul-CNPq
}

\section{UMA HISTÓRIA CRUENTA DA VIOLÊNCIA POLÍTICA}

A América Latina, parte sul do continente americano, desde suas raízes coloniais, espanholas e portuguesas, tem um histórico de violência política, protagonizado primeiramente por colonizadores interessados em subjugar os povos autóctones, a pretexto de cristianizá-los, e explorar as riquezas naturais da região. Depois, o domínio europeu foi continuado por seus substitutos crioulos, após os processos de independência, identificados com o mesmo e antigo sistema de mando, buscando o alto da pirâmide social a qualquer custo, do suborno ao assassinato. Segundo Pierre Chaunu, "Mais do que a paixão da aventura, e do que o zelo missionário, o motor da conquista foi a ânsia do lucro. Tal como Cristóvão Colombo, os conquistadores partiram em busca de montanhas de ouro que recuavam para os limites do horizonte e que, finalmente, os levaram ao fim do mundo" (24-6).

Hibridismos políticos fundiram governantes coloniais prepotentes e proprietários de terras usurpadas a seus legítimos donos, numa nova classe de espoliadores, da Argentina à Bolívia, do Chile ao Brasil. Destituídos de suas próprias culturas, os nativos oprimidos e as levas de escravos e de europeus empobrecidos que mais tarde vieram fazer a América acabaram como massas de manobra, o que determinou o estabelecimento de pseudorrepúblicas, dominadas primeiro pela força militar e posteriormente pela força simbólica.

Nos países latino-americanos, a história de sua formação e desenvolvimento vem banhada em sangue, seja de guerras entre nações, para delimitar fronteiras, ou de guerras intestinas, para assegurar privilégios. As guerras guaraníticas, decorrentes do Tratado de Tordesilhas, no século XVII, ou a Guerra do Paraguai, no século XIX, exemplificam bem as reivindicações territoriais. A Guerra dos Farrapos, no Rio Grande do Sul (1835-1845), contra o império brasileiro, espelha a disputa por riquezas, assim como a guerra do Chaco, entre Paraguai e Bolívia (1832-1835), e a Guerra do Pacífico, entre Chile, Peru e Bolívia (1879-1883). 
Saído de heranças claramente discricionárias, de cunho totalitário, o conceito de democracia, entre as nações latinas, foi redefinido como eleições fraudadas, em que a representação da vontade do povo tem sido reescrita como reconhecimento da superioridade das oligarquias, desde as assentadas nos princípios de servidão do velho feudalismo até as sustentadas pelo acúmulo do capital. Em tempos modernos, de crença no progresso que seria decorrente da ciência e da industrialização, livrando o homem do esforço físico e produzindo fartura para todos, pouco se modificou o panorama social, embora a educação universalizada, defendida pelo Iluminismo, tenha surtido frutos de conscientização e revoltas populares em diversas regiões do mundo e também neste continente.

Entretanto, os anseios de emancipação se chocaram com a herança colonial, pois a modernização esperada não alterou a tendência às imposições pela força e não mudou o status das massas dominadas. Acirraram-se os conflitos entre trabalhadores e patrões, entre camponeses e proprietários de terras, com poucos resultados libertários por toda a América Latina.

No século XIX, a perspectiva de liberdade tomou um novo impulso, graças à doutrina Monroe, lançada em 1823, que incentivou a solidariedade interamericana e promoveu reuniões com os chefes de Estado das Américas para dirimir conflitos, fortalecer a unidade entre as nações e estabelecer alianças comerciais. Havia, por trás dessa política de Washington, um intento imperialista, no sentido de assegurar um mercado e insumos primários.

A política do Big Stick, de Theodore Roosevelt, em 1901, logo se revelou como estratégia para proteger os interesses norte-americanos e resultou em intervenções no Panamá e na Nicarágua, na Venezuela e em Cuba, sob o pretexto de mediar crises e manter a paz continental. Mesmo a política da Boa Vizinhança, de Franklin D. Roosevelt, já nos anos 1930, que tentou corrigir os rumos colonialistas de seu predecessor e consolidar as relações internacionais com a América do Sul, criou laços de dependência com seus pesados investimentos visando garantir a defesa do hemisfério diante da Segunda Grande Guerra e da ameaça da expansão comunista.

Os sistemas de opressão e manipulação das massas, durante o século XX, apenas se sofisticaram. Movimentos operários e camponeses, assim como mobilizações estudantis, afloraram, mas seus sucessos eventuais também foram frustrados. Tomemse como exemplos Perón na Argentina, ou Getúlio no Brasil, nos anos 1930, ou ainda Pinochet, no Chile, nos anos 1970.

No Brasil, as tentativas de emancipação se multiplicaram ao longo dos séculos, desde o XVI até o XX, em que os dois governos Vargas, em 1930 e 1951, e o de Juscelino Kubitscheck, em 1956, buscaram modernizar o país, deslocando o foco econômico do campo para a cidade e a industrialização. A reação dos segmentos conservadores não permitiu que as parcas conquistas sociais vingassem. Os regimes que os sucederam,

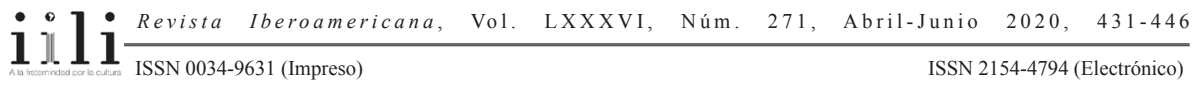


desde 1961, de Jânio Quadros a Jango Goulart, especialmente o último, de inclinação socialista, também geraram forte oposição. Aumentaram-se as tensões sociais e se abriu espaço para a intervenção das forças armadas, que em 1964 tomaram o poder, instituindo uma ditadura militar com duração até 1984.

O período seguinte foi o denominado de "anos de chumbo", em que os mecanismos de controle social se enrijeceram, com violações dos direitos civis, perseguição ao pensamento divergente, aos movimentos de rebelião, especialmente àqueles que as forças armadas consideravam subversivos à ordem nacional e que se espelhavam nas revoluções socialistas mundo afora.

Sucederam-se os presidentes de farda: Castello Branco (1964), que decretou o Ato Institucional No. 1 (AI-1), facultando que os mandatos políticos fossem cassados e a estabilidade dos funcionários públicos anulada; Costa e Silva (1967), que, em 1968, decretou o Ato Institucional No. 5 (AI-5), aposentando juízes, cassando mais mandatos, inclusive cargos de professores e cientistas, e aumentando a repressão militar e policial, o que favoreceu os "desaparecimentos" de opositores do regime em virtude da anulação do instituto do habeas-corpus; e Garrastazu Médici (1969), que intensificou em ampla escala a repressão às guerrilhas e impôs severa censura aos meios de comunicação. Nos governos seguintes, desencadeou-se um generalizado descontentamento popular e iniciou-se um afrouxamento do regime, com Geisel, que anula o AI-5, e depois com Figueiredo, que finalmente proclama a Lei da Anistia, em 1979, e reinstitui o pluripartidarismo.

O golpe militar brasileiro teve sua contrapartida nas ditaduras da Argentina, do Uruguai e do Paraguai, na ditadura chilena e na boliviana, que foram tão duras e insensíveis quanto a nacional. Estimuladas pelos Estados Unidos ao combate feroz às insurgências socialistas que tentavam emancipar seus respectivos países, foram responsáveis pelo período mais cruento da história das Américas após a colonização.

A intervenção norte-americana começara em 1961, por iniciativa do presidente John F. Kennedy, e reuniu 22 países continentais, salvo o Canadá e Cuba. Denominada Aliança para o Progresso, prometia o investimento de 20 bilhões de dólares no decênio para o crescimento autossustentado dos países-membros. Seus resultados, porém, só acirraram o ressentimento latino-americano contra os EUA, como confirma notícia de O Globo, publicada em 17 de setembro de 2013, de que "em 1972 cerca de 40\% dos trabalhadores latino-americanos estavam desempregados, a dívida externa dobrara e a miséria e desigualdade social continuavam intactas" (“John Kennedy").

$\mathrm{O}$ combate às insurreições comunistas na esfera latino-americana foi incentivado pelos norte-americanos e a Operação Condor, na década de 1970, aparatou os regimes de exceção, então em pleno vigor na Argentina, Bolívia, Brasil, Chile, Paraguai e Uruguai, com técnicas antiguerrilha e de obtenção de informações sob tortura e inteligência militar avançada, como bancos de dados computadorizados, além de 
suscitar operações conjuntas multinacionais, que constituíram um decisivo reforço à repressão institucionalizada.

Segundo a Comissão da Verdade brasileira, a Operação formalizou, em 1975, a aliança das ditaduras do Cone Sul desde os anos 70, "para a realização de atividades coordenadas, de forma clandestina e à margem da lei, com o objetivo de vigiar, sequestrar, torturar, assassinar e fazer desaparecer militantes políticos que faziam oposição, armada ou não, aos regimes militares da região" (Comissão Nacional da Verdade).

Levando em conta todo esse espectro perverso de condições políticas e institucionais, envolvendo as relações exteriores dos Estados Unidos com a América Latina e o Brasil, Erico Verissimo assenta suas lentes sobre a má formação do Estado brasileiro, desde a colonização até a república, como processo propício à instalação da ditadura militar de 1964. Em seu último romance, Incidente em Antares (1971), revisita a história de seu estado, o Rio Grande do Sul, desde o Pleistoceno até a margem dos regimes de força atuantes nos anos 1960-1970 ao sul do continente.

\section{A PROdUÇÃo DE INCIDENTE em ANTARES EM ÉPOCA DE REPRESSÃo POLÍtiCA}

Ahistória da produção de Incidente em Antares se insere no furor da ditadura militar brasileira. Em entrevistas realizadas após a publicação, em 1971, Erico informa que o romance começara a ser concebido em 1969, a partir de outro projeto, com o título provisório de Dança com máscaras, quando "andava impressionado (e ainda ando) com a crescente dose de mentiras, fantasias e 'empulhações' de nossa vida cotidiana" (Gastal e Przybylski 21). Ele pretendia situar sua nova história em Porto Alegre ou no Rio, reintitulada de $A$ hora do sétimo anjo, tematizando a hipocrisia e o individualismo na alta sociedade. Uma fotografia, vislumbrada de passagem na revista nova-iorquina Time, de uma greve de coveiros levou-o a pensar no que aconteceria se aqueles mortos fizessem greve contra os vivos. A ideia, na ocasião, lhe pareceu insensata, pois não seria verossímil uma greve de coveiros no Brasil (Fernandes).

Naquela época, firmava-se na América do Sul o processo de legitimação do Estado ditatorial que dava ao exército "o papel de censor da vida política. Nasce depois da Segunda Guerra Mundial, como consequência da aparição do poder nuclear, que deixa os exércitos regionais incapazes de assegurar a defesa externa de seus países contra uma potência dessa ordem" (Mix 14; tradução minha). Miguel Rojas Mix observa que essa lógica entende a política como continuação da guerra, levando o exército a assumir o poder, ocupar o seu país e reprimir a sociedade civil para torná-la subserviente. Erigese a segurança nacional como padrão político, gerando a violação permanente dos direitos humanos, pois se recorre a qualquer método de força para atingir os inimigos do Estado (14-15). É o que acontecera em 1964, com o golpe militar, e que Erico Verissimo observava apreensivo, pois sua posição política era de um liberal, a quem a

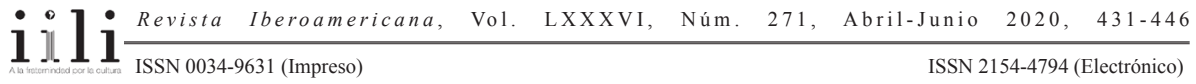


liberdade de opinião e de ação era essencial, e ele estava a par da escalada de greves no país e da reação do regime.

É possível que acreditasse estar a situação crítica do país radicada na hipocrisia da moralidade burguesa, o que justificava sua dedicação ao romance que continuaria seu ciclo urbano, mas a foto persistiu na lembrança (e a repressão da ditadura se acentuou com o AI-5), de modo que, em 8 de maio de 1970, caminhando com Mafalda no Alto Petrópolis, "a ideia me voltou com tanta força que comecei a trabalhar nela mentalmente". E, ao alcançar a esquina da Avenida Carlos Gomes com a Protásio Alves, "o livro já estava estruturado" (Gastal e Przybylski 21). O ponto inverossímil foi resolvido por meio de uma greve de operários que interditaria o cemitério.

A composição do romance é documentada pelo diário que Verissimo manteve durante a estada com sua filha Clarissa nos Estados Unidos (Diário 1970), cujo primeiro registro aparece no dia 29 de junho. Constata-se que escreveu a primeira parte, "Antares", inteiramente na Virginia, que seu maior obstáculo foi dar conta de uma larga fatia da história, selecionando os eventos tendo em vista o incidente-chave, sem incidir na repetição dos processos de ficcionalização empregados em $O$ tempo e o vento. Também ali, à janela da casa em McLean, à vista do pátio e da mata aos fundos, elaborou a pesquisa do sociólogo Martim Francisco Terra e esboçou as cenas principais da segunda parte. Seu diário termina em 12 de dezembro, e ele regressa a Porto Alegre no mesmo mês. Passa janeiro de 1971 sem escrever e depois retoma o trabalho com entusiasmo.

Seu caderno de notas (Verissimo, Notas), indicia a presença de $O$ homem rebelde/O mito de Sísifo, de Camus, como fonte filosófica para Martim Francisco, o intelectual que resiste às pressões dos poderosos com a força do conhecimento. A personagem também homenageava um eminente cientista social da Universidade Federal do Rio Grande do Sul, Leônidas Xausa, seu amigo, expurgado em 1969. Nos rascunhos de Incidente (Verissimo, Esboços), evidencia-se que, do romance antes planejado, Erico se valeu apenas de alguns trechos referentes a Martim Francisco e Valentina. Há roteiros prévios, só em parte aproveitados, há fragmentos de ideias, recados e advertências para si mesmo, desenhos a esmo, comentários sobre o caráter das personagens, sobre programas ideológicos, sobre os fatos históricos a serem utilizados, há remissão a fontes paralelas, além de passagens incompletas da história. Essa matéria informe e fragmentada indica que o autor se entregava com dificuldade à composição da obra, e se autoexaminava concomitantemente, em meio a períodos de bloqueio e inação, a fim de não perder o fio e o foco do enredo, garantindo a coerência e a unidade final do texto.

Talvez o inusitado incidente-absurdo do ponto de vista lógico-viesse a chocar-se com o estilo usualmente realista da literatura de Erico, levando-o a hesitar e reescrever trechos e trechos, além de confrontá-lo imaginariamente com a presença constante da morte, seja na parte histórica, seja na praça de Antares, num período em que morrer se

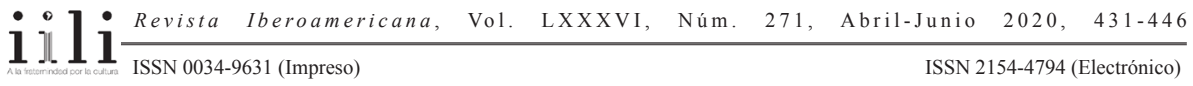


tornara um lugar comum para quem resolvesse opor-se ao regime. Erico, bem informado pela imprensa norte-americana sobre o que se passava no Brasil, conhecia os esforços de intelectuais universitários, de preeminentes representantes dos movimentos católicos e protestantes, inclusive de Martin Luther King, Jr., nos Estados Unidos, em favor do fim da repressão no Brasil. Como confirma Carlos Fico, "vários desses estudiosos, como o próprio Thomas Skidmore, participaram, nos Estados Unidos, de manifestações de condenação à ditadura militar, além de apoiarem brasileiros refugiados naquele país, e o fizeram de maneira bastante discreta, sem reclamar gratidão" (30). Em apoio a essa informação, o historiador James Green menciona dois comitês então organizados, o American Committe for Information on Brazil e o North American Congress on Latin America (NACLA), em 1967, que mobilizaram professores, estudantes, exilados latino-americanos, esquerdistas católicos, voluntários do Peace Corps e militantes do movimento pacifista, na divulgação das violações do regime ao direitos humanos e que estudavam questões socioeconômicas e políticas do Brasil (87-117).

Não só do lado norte-americano, Erico sabia das ações discricionárias dos militares, pois acompanhara de perto as cassações ocorridas no Rio Grande do Sul, especialmente em PortoAlegre, de acadêmicos com quem ele mantinha amizade, punidos por exercerem o direito de livre pensamento. Tinha diante de si o desafio de rever a história brasileira e a de seu estado, buscando as raízes dos acontecimentos contemporâneos, e ao mesmo tempo construir uma fábula que evidenciasse o significado da ditadura de Estado ao cidadão que, àquele momento, já se tornara vítima dos mitos de legitimação que se fixam como parte do "imaginário de classe, do imaginário nacional, ou circulam através do senso comum, expressando-se em reflexos racistas, sociais e culturais" (Mix 17, tradução minha).

Os originais de Incidente em Antares foram entregues à Editora Globo em 1971, iniciando outro período de incertezas, desta vez em virtude da promulgação da Lei da Censura Prévia (Decreto-Lei n. 1077), de 1970, por Garrastazu Médici. Fundamentada na Lei da Segurança Nacional (Decreto-Lei n. 898), de 1969, a Censura Prévia atingia a imprensa em todas as suas formas, falada, escrita e televisiva, inclusive a indústria editorial. Erico Verissimo e Jorge Amado, ao saberem do ato discricionário, manifestaram publicamente, nos jornais, seu repúdio à medida, declarando que não se submeteriam à referida Lei.

Os dirigentes da Editora Globo ficaram apreensivos ao lerem os originais. Leve-se em conta que, de 1970 a 1978, os temas proibidos de circular eram notícias sobre ações da repressão (36\%) ou ações da oposição (36\%), problemas do regime (12\%), questões sociais (6\%), assuntos econômicos (5\%), outros temas (5\%) (Soares, "Censura”). Entre os outros temas, a Censura Prévia incidia, na área da literatura, sobre imoralidade, cenas de sexo, perversões, embora não reprimisse alusões à violência. $\mathrm{O}$ romance de Erico reunia sobejos motivos para ser enquadrado nessas diversas classificações,

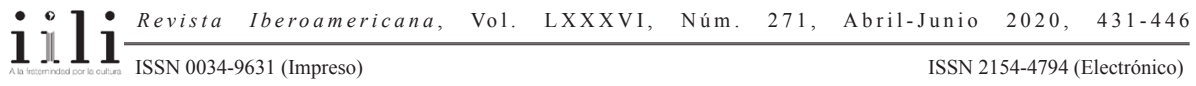


arriscando-se a ser apreendido tão logo fosse publicado. Diz seu editor, José Otávio Bertaso: "De imediato, percebi que a história de Verissimo era extraordinariamente envolvente e de forte cunho político, quase explosivo para os padrões da época" (41).

A Globo resolveu esquivar-se da Censura e garantir a circulação do livro através de três medidas: a primeira foi obter do Instituto Nacional do Livro, na época dirigido por Maria Alice Barroso, uma manifestação de interesse de coedição. De posse dessa carta-intenção, Bertaso tomou a segunda providência. Compareceu a uma reunião no Terceiro Exército, com o General Rui de Paula Couto, e submeteu-lhe cem provas da obra, que foram examinadas e liberadas sem que os militares soubessem do restante, então em composição. A terceira foi expor o livro publicado nas vitrines com um grande cartaz (também previamente aprovado pelos militares) e vendê-lo com uma cinta, onde se lia "Num país totalitário, este livro seria proibido" (Bertaso 42). Os estratagemas surtiram efeito-o general, mais tarde, qualificou o livro de "tinhoso"-e a primeira edição esgotou-se de imediato, pois as camadas mais avisadas do público temiam a proibição de comercialização e de reedição. Sucesso de público e de crítica, só no ano de 1971, 30.000 exemplares foram vendidos.

\section{ANTARES E A LEI DO MAIS FORTE}

Toda a arquitetura da primeira parte do romance, intitulada "Antares", reconstitui a história do Rio Grande do Sul, desde os tempos pré-históricos até o governo Goulart. O tratamento histórico é realizado por meio de um narrador onisciente, que várias vezes cede sua voz a documentos citados, sejam relatos de viagem ou diários pessoais e reportagens de jornal. A dominante estilística é a paródia irônica (Hutcheon 54-64), que já inicia quando o narrador informa ter sido desencavado, nas terras de Antares, um fóssil de gliptodonte, animal antediluviano do Pleistoceno, e acrescenta que, no mesmo período, bandos de megatérios pastavam na região às margens do rio Uruguai, na fronteira com a Argentina. Símiles dos futuros habitantes de Antares, sugerem que estes serão lerdos de movimentos, inclusive de inteligência, e que serão constantemente ameaçados por predadores.

Anunciando de antemão que o aziago incidente ali ocorrido em 13 de dezembro de 1963 atingiu todo o mundo civilizado, o narrador passa a situar o palco e o elenco da história, citando a visita do naturalista Gaston Gontran d'Auberville ao Povinho da Caveira, que, em seu diário, conta ter mostrado a Francisco Vacariano, que o hospeda, a estrela Antares, adotada como nome da povoação pelo fazendeiro, "homem violento e vingativo" (22), cujo gado descendia do que seu pai roubou durante as guerras com a Banda Oriental, e cujas terras, herdadas das sesmarias do avô, haviam sido expandidas por extorsão, afugentando à força os outros estancieiros. O depoimento é secundado pela carta do Padre Juan Bautista Otero a seu provincial, mencionando as luxúrias de

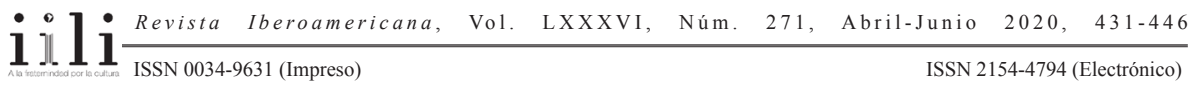


Bacariano com as indígenas e suas preocupações com a imoralidade despreocupada do estancieiro. O episódio já caracteriza que o chefe do povoado é inculto e adepto da força para aumentar seus domínios.

Chico Vacariano teve sete filhos e quase perdeu seus bens durante a Guerra dos Farrapos, mas safou-se negociando com um e outro lado. Refugiado na Argentina, restaurou suas propriedades ao fim da guerra e continuou a autoridade principal da recém vila, em 1853, como fora no Povinho da Caveira desde 1821. Só em 1860 sentiu-se ameaçado com a vinda de outro estancieiro abastado, Anacleto Campolargo, homem "sinuoso e macio" (28). A primeira vez que se defrontaram, na praça do Império, odiaram-se de pronto. Assim surgiram as duas dinastias de Antares, cuja rivalidade política, econômica e pessoal duraria sete décadas.

Caracterizados os próceres, também se indicia o clima de permanente conflito pelo poder que se seguirá. Episódios marcantes, envolvendo os filhos, são a Guerra do Paraguai, de 1865 a 1870, em que Antonio Vacariano é morto, e Benjamin, Gaudêncio Campolargo e Antão Vacariano voltam mutilados, vindo Benjamin e Antão a substituir os pais falecidos no mando da região. Rivais políticos, um era do Partido Liberal e o outro do Republicano, confrontando-se outra vez por ocasião da abolição da escravatura, em 1888, e com a queda do Império, em 1889.

A revolução federalista de 1893, no Rio Grande do Sul, resulta na degola de Antão, derrotado em combate, por ordem de Benjamin, e leva à vingança dos Vacarianos, comandados por Xisto, contra Terézio Campolargo, originando uma das cenas mais bárbaras do romance, quando Xisto manda derramar azeite fervente nas entranhas do oponente. A tortura é paga mais tarde por Benjamin, mandando estuprar Romualdo Vacariano, que se suicida.

Xisto Vacariano e Benjamin Campolargo, nas décadas seguintes, rivalizam não só pelo poder político, mas pelo prestígio social. Como Benjamin angaria as boas graças de Borges de Medeiros, o novo presidente do estado, pode prosseguir em seus desmandos de chimango: "continuou a perseguir a oposição, a coagir juízes, promotores e jurados. Governava despoticamente o município de Antares, onde os maragatos eram minoria" (41).

Novas gerações se sucedem e se civilizam, de modo que, ao fim dos anos 20, Xisto e Benjamin "pareciam-se um pouco com os gliptodontes e megatérios no fim do Pleistoceno, isto é, eram dois representantes de espécies animais em extinção" (46). Levados pela habilidade política de Getúlio Vargas, reconciliam-se, mas cedo o Campolargo morre de edema pulmonar e o Vacariano de uma chifrada. Seus sucessores são Tibério Vacariano, casado com Briolanja, e Zózimo Campolargo, este com Quitéria.

Introduzidos os dois rivais agora amigos, a trajetória de Antares segue sob o tacão de Tibério, que auxilia a trajetória ascensional de Vargas, fraudando as eleições para Presidente da Província. O coronel induz "os pica-paus a falsificar atas fazendo todos os defuntos do cemitério local votar no seu candidato" (52). Com a vitória de

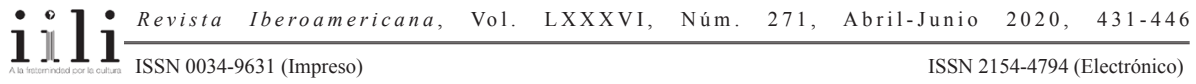


Vargas, em 1930, Tibério logo vai ao Rio pedir vantagens para amigos e parentes na administração federal, quando se familiariza com a corrupção que secunda o poder político, as negociatas e os jogos de "pistolões”. E tenta converter Zózimo com um discurso fascista contra as democracias liberais: "Somos um país subdesenvolvido de analfabetos e indolentes. É indispensável unificar e organizar a nação com punho de ferro", defendendo Mussolini e Hitler. O amigo o acusa de racista, e Tibério retruca, indignado: "Sabes como trato a minha negrada. Eles me adoram". E comparando o país com os Estados Unidos, conclui: "no Brasil a gente, graças a Deus, não tem esses problemas, pois aqui o negro conhece o seu lugar" (57). Tibério reúne todos os atributos do oligarca conservador e preconceituoso, de certo modo em oposição a um Zózimo um tanto mais liberal.

Tibério, no Rio, torna-se o modelo do político oportunista. Monta um escritório de advocacia, ganha comissões polpudas para acelerar processos emperrados na burocracia, e enriquece em transações imobiliárias e no câmbio negro. Vive "à sombra do Banco do Brasil, do qual conseguia empréstimos para amigos e sócios, e para si mesmo" (59). Tem negócios ilícitos durante a Segunda Grande Guerra e acumula dólares em banco suíço, bem como instala em Antares uma falsa fábrica de seda para dar vazão legal a contrabandos do Uruguai, aproveitando-se das vantagens políticas adquiridas. Com a redemocratização do país, em 1945, Tibério trata de retirar-se da vida pública. Fecha a fábrica, orgulhando-se secretamente de ter feito "suas trapaças sem ficar com o rabo preso" (64).

Com a nova ascensão de Vargas à presidência em 1951, pelo voto do povo, os movimentos de reivindicação de direitos trabalhistas perturbam Tibério, que vê em Antares os operários se organizarem. Perdendo seu antigo prestígio no Rio, onde em vão tentou refazer sua rede de influências, conhece um chinês interessado em implantar uma fábrica de óleos comestíveis, a quem oferece cinco anos sem impostos, terreno, material de construção a preços baixos, garantindo comprador para a soja que cultivava. A vida volta à rotina, até que a crise política nacional eclode. $\mathrm{O}$ atentado a Lacerda precipita a situação, as forças armadas reagem exigindo a renúncia de Vargas, que se suicida. O povo se amotina, há depredações nas cidades, em especial em Porto Alegre, mas Tibério se preserva e não vai ao enterro. Também não se alia ao herdeiro de Getúlio, Jango, e rejeita o novo presidente eleito, Juscelino Kubitschek. Zózimo falece e Quitéria se coloca, embora com restrições, ao lado de Tibério.

A subida de Jânio Quadros ao poder, tendo Jango como vice, deixa Quitéria desconfiada, por suas ideias "socialistas", enquanto Tibério, tentando manter-se bem com o novo governo, apoia a campanha eleitoral, mas, após conhecer o ambiente de Brasília, volta dando um ano de sobrevida ao presidente. Jânio renuncia em 1961 e Jango se torna presidente, em 1963, após um breve período de parlamentarismo, iniciando um governo com ares de esquerda, visto com preocupação crescente pelos Vacarianos e Campolargos.

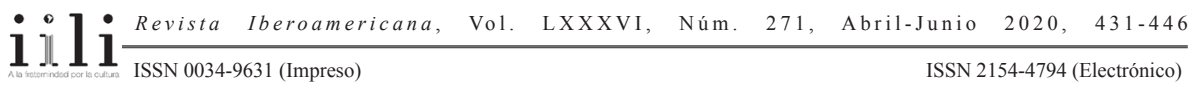


A essa altura da narrativa, está montado o palco histórico em que se desenvolverá o incidente: uma cidade violenta, sufocada pela força bruta e corrupção de seus próceres, com um movimento operário ainda tímido, mas já manifestando sua contrariedade. Tibério e Quitéria, os sobreviventes dos dois clãs que sempre imperaram em Antares, estão suficientemente caracterizados, ambos apoiadores das hostes da direita.

É importante salientar que o narrador não faz ouvir apenas a sua voz para denominar e descrever essa comparsaria. Vale-se do discurso indireto e do diálogo para que as posições ideológicas das personagens se expressem sem sua interferência, dando o exemplo de um trânsito linguístico antes de tudo democrático. Entretanto, em relação aos eventos a serem narrados, pertinentes à vida de suas criaturas, percebe-se o viés irônico e crítico com que os seleciona e avalia, configurando sua narrativa como a metáfora do Brasil autoritário.

É nessa instância do romance que Erico interrompe a continuação da história, pela inserção do estudo sociológico do Professor Martim Francisco Terra, de que narra o contexto de produção, os resultados da pesquisa e a recepção obtida na cidade. Publicado em 1965 pela Fundação Ford, sob o título de Anatomia duma cidade gaúcha, o trabalho, inicialmente recebido com entusiasmo pelos cidadãos de Antares, em 1961, logo desperta desconfiança nas diversas camadas da população.

$\mathrm{O}$ inquérito, que introduz a narração do Incidente e coroa a da história pregressa da cidade, diagnostica os males das cidades interioranas brasileiras, de que é posto como caso-modelo. Assumindo um discurso supostamente objetivo, o das Ciências Sociais, analisa a constituição social de Antares. Sua neutralidade, porém, é inflectida pelas anotações afetivas do diário de Martim Francisco. No fundo, os dois testemunhos confirmam uma estrutura urbana desigual e injusta, mas são animados por uma possibilidade de mudança, anunciada pelas reformas do governo Jango. O sociólogo, entretanto, terminado o trabalho, confessa a seu aluno seus receios de que as esperanças venham a frustrar-se: “Tudo indica que essa revolução, que já está sendo contestada, contribuirá a encontrar uma resistência cada vez mais forte. E é natural que a contestação provoque a repressão e a repressão mais contestação". E lamenta: "não me surpreenderei se qualquer dia entrarmos numa era de terrorismo" (147).

Concluída a exposição sobre a formação da sociedade antarense, dos pontos de vista histórico e sociológico, todos os elementos estão explicitados para justificar o inexplicável: o despertar dos mortos insultados pelo insepultamento decorrente da greve dos coveiros.

\section{O INCIDENTE E A METÁFORA DOS REGIMES DE EXCEÇÃO}

A história começa quando a ameaça de greve geral leva Tibério Vacariano a apelar ao governador do Estado por tropas da Brigada Militar para impedir que o movimento se desencadeie. Como o governador recusa, porque a Constituição vigente garante o

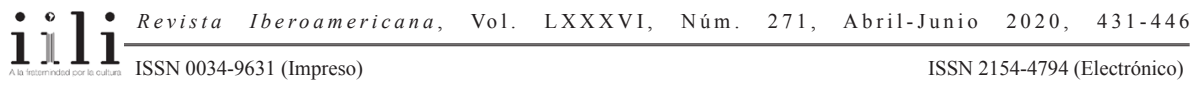


direito à greve, o Coronel se inflama: "Chegou a hora do Exército Nacional entrar em cena, empolgar o poder em nome do povo, da tranquilidade geral e da justiça" (194).

A greve eclode ao meio-dia de 11 de dezembro de 1963, mobilizando os operários do Frigorífico Pan-Americano, os da Cia. Franco-Brasileira de Lãs e os da Cia. de Óleos Comestíveis Sol do Pampa. Os da Usina Termoelétrica Municipal cortam a luz e todos os envolvidos na economia de serviços aderem à greve. O prefeito convoca a Câmara Municipal sem efeito algum, tenta conciliar os interesses dos grevistas e dos patrões, mas não há negociação possível.

Já no limiar do Incidente, pontos-chave são enfatizados: operários não podem interromper a produção, governantes rejeitam reivindicações ao arrepio dos direitos garantidos pela Constituição, elites acreditam que o Presidente e o Vice estão arruinando o país e que só os militares podem impedi-los. Além da óbvia remissão à luta de classes, registra-se com clareza que os representantes políticos do povo, como em muitos regimes autoritários, advogam a sua erradicação pela força das armas.

Enquanto isso, D. Quitéria morre de enfarto, um pianista fracassado, Prof. Menandro, se suicida, o sapateiro anarquista José Ruiz, vulgo Barcelona, sofre um aneurisma. $\mathrm{O}$ operário Joãozinho Paz sucumbe à tortura do chefe de polícia, o advogado das elites, Cícero Branco, tem um AVC, a prostituta Erotildes é levada pela tuberculose e Pudim de Cachaça é assassinado pela mulher, que não suporta mais suas bebedeiras.

Os defuntos, representativos das diversas classes e camadas sociais de Antares, são abandonados no cemitério e literalmente despertam da morte na madrugada do dia 12 . Como se não estivessem mortos, mantêm sua memória e suas concepções de vida e, tomados de profunda indignação, marcham em protesto para a cidade, insuflados por Cícero, que planeja usar uns papéis incriminadores para dar um ultimato ao prefeito e requerer o sepultamento dentro de 24 horas.

Os mortos passam antes em suas casas, acertando contas com os vivos. O narrador escolhe essas personagens para estabelecer uma posição moral e efetuar uma crítica social implícita: os mais abastados, como D. Quita e Cícero, são traídos até pela família, os mais destituídos, como Erotildes e Pudim, contam com a solidariedade dos amigos, e os olhados de viés pela sociedade, como o sapateiro anarquista e o pianista fracassado, saem-se bem sucedidos em seus contatos post-mortem.

Os pró-homens de Antares confabulam para tentar resolver o caso enquanto os mortos marcham para o coreto da praça e se recusam a deixá-lo se não forem sepultados. Está montado o palco de um macabro tribunal diante de toda a população de Antares. O prefeito informa o fracasso das negociações em tom de vítima da intransigência dos grevistas: "Não quero lançar contra os operários tropas estaduais ou federais porque [...] sou um homem avesso à violência”. E oferece aos mortos transporte gratuito ao cemitério, depois de os ameaçar: "Pela mesma razão não pretendo hostilizar-vos, pois isso seria uma injustiça. Sois antarenses como nós. A morte não vos roubou a cidadania!"' (335).

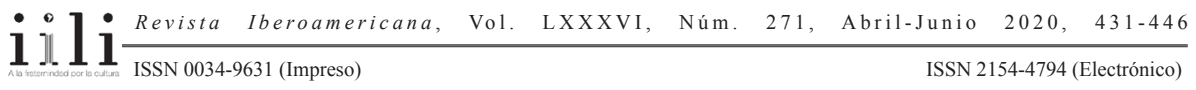


Cícero, em resposta, atuando como promotor menciona o "baile de máscaras" da sociedade antarense e denuncia a Grande Festa da espoliação, cujos protagonistas assinala, incluindo a si mesmo: o Prof. Libindo, o Dr. Lázaro, o juiz, Dr. Quintiliano, o Prefeito Vivaldino (associando-o a Dr. Jekill e Mr. Hyde), o Dr. Falkenburg, o delegado Pigarço, o presidente do Rotary e o do Lions, o jornalista Lucas Lesma, as produtoras de cartas anônimas, irmãs Balmacedas. Para ele, só o Cel. Vacariano "ostenta com naturalidade e coragem cívica o manto antipático do poder discricionário" (342), mas documenta seus crimes, declarando que "o nosso Tibério, imperador de Antares, adora a Propriedade, e é capaz de matar e até de arriscar-se a morrer para defender as suas propriedades, aumentando-as à custa da propriedade alheia” (318).

Erico recorre a lugares comuns da retórica dos políticos e juristas para ironizar o debate, na pessoa de um advogado arrependido, encarregado da acusação, que em seguida dá lugar a suas testemunhas. A primeira é D. Quitéria, a lamentar, partindo do que viu em sua família, que, "Hoje em dia as pessoas prezam mais os objetos do que os outros seres humanos" (319). Barcelona censura os falsos moralistas e arrola as aventuras sexuais do comendador Armendariz com ninfetas, e os adultérios da filha de Quitéria. Erotildes acusa o "humanitário" Comendador Leoverildo de tê-la deflorado, e de ter sido mantida por Vacariano como sua amásia e depois ter sido abandonada e entregue à vida. Com tuberculose, morre porque o Doutor Lázaro não providenciou a penicilina que a curaria. Pudim de Cachaça implora pateticamente que absolvam sua mulher.

Tópico a parte é João Paz, apontado como vítima do torturador Pigarço, com a cumplicidade dos dois médicos que atestaram embolia pulmonar como causa mortis. Acusa-os Cícero: "Acho que todos poderão ver estas manchas arredondadas na cara e nas mãos de João Paz [...] Pois foram produzidas por pontas de cigarros acesos" (328). Além disso, informa que, para obrigá-lo a dedurar um grupo de guerrilheiros inexistente, "dois brutamontes puseram-se a bater em Joãozinho, aplicando-lhe socos e pontapés no rosto, na boca do estômago e nos testículos [...]" (329). E compara o olho exorbitado do operário a um ovo de codorna, e os hematomas das pálpebras e da pele ao redor dos olhos a uma folha de repolho roxo (329). Cícero descreve o restante das sessões de tortura (choques elétricos nos genitais, afogamento-em tudo iguais aos que se praticaram no país durante a ditadura militar) e acusa o Dr. Lázaro de acobertar a morte da vítima, a mando do prefeito.

$\mathrm{O}$ acusador e os mortos-testemunhas silenciam, o julgamento acaba e a multidão horrorizada se dispersa. A população de Antares, de portas e janelas fechadas, em pânico na cidade infestada de ratos, não reage às denúncias dos mortos, patenteando sua despolitização e submissão à oligarquia que a comanda. A noite cai e várias personagens são visitadas pelo olhar onisciente do narrador, que os surpreende sofrendo os efeitos do choque, mas sem modificarem comportamentos. O prefeito decide apelar pela força. Os mortos, atacados e semidespedaçados pelos seus “embuçados da alvorada” a pedras, 
garrafas e pedaços de madeira, resolvem voltar aos féretros, às seis e vinte de 14 de dezembro de 1963. São enterrados, e a cidade suspira aliviada, apesar de inquieta.

Por meio de várias vozes narrativas, o "incidente" é focalizado de diversas perspectivas, recebendo toda espécie de explicações, da crendice à ciência. Os segmentos oprimidos da população obtêm voz, mas os poderosos não a ouvem; desmentem-se as falsidades dos opressores, mas logo são esquecidas. No interior da narrativa, a denúncia realizada pelos mortos das arbitrariedades e violência institucional e todo o horror presenciado tornam-se rapidamente inócuos. A cidade ressurge: "Deus é bom. Cedo, na manhã daquele sábado-verdadeira aleluia para os antarenses-um vento forte começou a soprar em Antares, de leste para oeste, varrendo na direção da Argentina e de outras repúblicas vizinhas, os miasmas e o mau cheiro deixado pelos mortos na Praça da República e arredores” (396).

A insistência da repetição das datas do Incidente, sexta-feira e sábado, sugerem uma relação com a Paixão e a Páscoa. Erico usa uma ambiguidade irônica (Hutcheon 61-63), em que a sexta-feira-da Paixão, dia de sacrifício-torna-se a hora da ressurreição de uma verdade perturbadora, enquanto o sábado-de Aleluia, em que Cristo vence a morte-enterra com alegria essa mesma verdade incômoda. A data de 13 de dezembro, por sua vez, remete diretamente à promulgação do Ato Institucional No. 5, em 1968, criando um paralelo simbólico entre o acontecimento e o que se seguirá, a sua ocultação, e os efeitos do referido Ato.

Antares, entrementes, não se recupera. A divulgação pela imprensa nacional e internacional da ocorrência humilha a população. Na segunda-feira, com a reabertura do comércio, "uma baça tristeza continuou a pairar sobre a cidade e as almas" (405). Para reerguer a moral dos cidadãos, o Prof. Libindo sugere ao prefeito "organizar uma campanha muito hábil, sutilíssima, no sentido de apagar esse fato não só dos anais de Antares como também da memória de seus habitantes" (408). Ele a nomeia como Operação Borracha, confiando no bom senso da população e no efeito do tempo para promover o esquecimento. (A ideia da Operação Borracha remete ao que a ditadura militar tentava fazer no Brasil dos anos 1970. Erico Verissimo, por meio desse expediente simbólico, alude, outra vez ironicamente, à prática autoritária dos governos de exceção de tentarem reescrever a história).

Em reação, a prefeitura organiza um jantar de gala em desagravo aos próceres maculados pelos mortos. No banquete, o torturador Pigarço é elogiado como "soldado que é da sociedade cristã ocidental", "atacada por grosseiros materialistas a soldo de Moscou" (413), e é aplaudido por três minutos. Do lado de fora, um bando de jovens vaia os homenageados e é dispersado pela polícia com gás lacrimogêneo-prenúncio da ascensão da repressão e das perseguições que logo se instalariam no país.

No mesmo sentido de antecipação, em visita a Antares, Martim Francisco e Xisto conversam com Tibério Vacariano, e o velho coronel declara que defenderá até a morte as suas ideias e propriedades contra todos os ataques comunistas. Martim Francisco

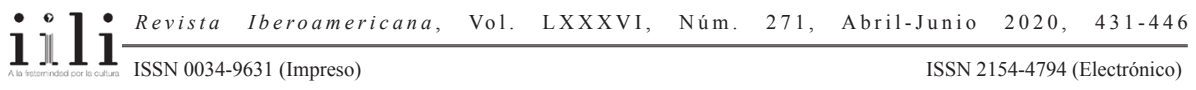


lhe pergunta por quanto tempo pensa poder manter seus privilégios e ele responde que sua classe tem um trunfo, o Exército: "As Forças Armadas, moço, um dia vão apertar os parafusos frouxos deste país. Precisamos, antes de mais nada, de ordem" (417). Se em Antares a situação social é insustentável, pelo horror do Incidente, ela serve de hipérbole para as crises de outras cidades brasileiras, que classes dirigentes enfrentavam nos anos 1960, aterrorizadas pelos movimentos populares de reivindicação.

Martim Francisco se encontra igualmente com seu amigo padre e regressa a Porto Alegre cheio de dúvidas sobre o acontecimento e com a convicção, que transmite ao despedir-se do Pe. Pedro-Paulo, de que "antes de cinco ou seis meses, se tanto, teremos um golpe de direita ou de esquerda, com a participação do Exército. Vença o lado que vencer, haverá sempre uma grande vítima: as liberdades civis" (419). Erico Verissimo utiliza a autoridade de cientista social de sua personagem como alter ego para expressar sua própria posição, de intelectual inconformado, nem à direita nem à esquerda, quanto à conjuntura que a nação atravessava nas décadas de 1960 e 70, em que a profecia de Martim Francisco já se cumprira.

O romance termina com o êxito da Operação Borracha e com o advento da "revolução vitoriosa", que Lucas Faia exalta pela proibição das greves e pela harmonia reinante entre patrões e operários, regozijando-se porque não há mais desordem social. Geminiano, o líder grevista, caçado pela polícia, se exila na Argentina; o delegado é transferido por méritos para uma cidade mais importante; Tibério morre e no enterro um jovem o compara a um dinossauro, membro de uma raça de "grandes répteis da vida pública" em extinção; o prefeito perde prestígio por não conseguir liderar a ARENA local; o Pe. Pedro-Paulo é transferido para uma freguesia obscura pelas autoridades da Igreja; Martim Francisco é expurgado da universidade e emigra para o Chile; e a alta sociedade de Antares se dedica a um "delírio exibicionista e competitivo, em matéria de posição e virtudes mundanas" (427). A prosperidade e a ordem, porém, não evitam os descontentes. Na calada da noite, vultos anônimos escrevem nos muros frases subversivas. Um deles é morto pela guarda municipal que no dia seguinte vem apagar a palavra proibida. Uma criança tenta lê-la, "Li-ber..." (428), imediatamente reprimida pelo pai.

O desfecho de Incidente em Antares é catastrófico, como a conjuntura do país à época. Desde o início, o drama estava preparado pela menção aos monstros préhistóricos e pela truculência das dinastias dos Vacarianos e Campolargos na manutenção do poder. A reviravolta, representada pela greve dos trabalhadores e pela rebelião dos mortos insepultos, não altera a situação primitiva. Suas denúncias não afetam o povo, manipulado pelas autoridades e aterrorizado pela decomposição progressiva de corpos ainda animados de uma vida incompreensível, tão incompreensível quanto a luta desproporcionada entre governo forte e o fraco movimento operário.

É assim que Erico Verissimo constrói a metáfora de Antares como a das sociedades latino-americanas dominadas, atravessando a história da formação de seu país, com

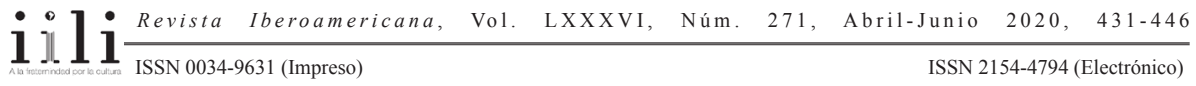


todos os lances de uma política espúria, desinteressada do bem comum. Figurando as instituições públicas como lugar de vantagens e privilégios, de manobras ocultas, de negociatas, de trocas de favores e sujeira moral, desnuda a sua violência desumana e retrata alegoricamente o que acontecia no Brasil. Pelo processo irônico da ambiguidade do sentido, são os corpos em decomposição que demandam justiça, os cidadãos de bem de uma sociedade corrompida. Todavia, seu limite é a morte, e é ela que desfaz sua determinação de luta.

\section{Obras Citadas}

Bertaso, José Otávio. A Globo da Rua da Praia. São Paulo: Globo, 2012.

Chaunu, Pierre. História da América Latina. São Paulo: Bertrand Brasil, n.d.

Comissão Nacional da Verdade. "Operação Condor e a ditadura no Brasil". <www.cnv. gov.br/index.php/2-uncategorised/417-operacao-condor-e-a-ditadura-no-brasilanalise-de-documentos-desclassificados>. 6 julio 2016.

"Erico Verissimo, o homem de Antares". Entrevista por Ney Gastal y Susana Przybylski. Correio do Povo (1971): 21.

Fernandes, Carlos M. "Verissimo: Evite o espelho mágico". O Estado de São Paulo. 12 março 1972: Suplemento Literário.

Fico, Carlos. Além do Golpe. Versões e controvérsias sobre 1964 e a ditadura militar. Rio de Janeiro: Record, 2004.

Green, James N. "Clerics, Exiles, and Academics: Opposition to the Brazilian Military Dictatorship in the United States, 1969-1974". Latin American Politics and Society 45/1 (2003): 87-117.

Hutcheon, Linda. Irony's Edge. The Theory and Politics of Irony. London: Routledge, 1995.

“John Kennedy cria aliança para o progresso virando a ConterComunismo". O Globo 17 sept. 2013. < http://acervo.oglobo.globo.com/fatos-historicos/john-kennedy-criaalianca-para-progresso-visando-conter-comunismo_10005300\#ixzz4DkVtIvnE>. 6 julio 2016.

Mix, Miguel Rojas. "La dictadura militar en Chile y América Latina”. Ditaduras militares na América Latina. Claudia Wasserman y Cesar Augusto Barcellos Guazzelli, orgs. Porto Alegre: Editora da UFRGS, 2004. 11-26.

Soares, Glaucio Ary Dillon. "Censura durante o regime autoritário". Anpocs. <www. anpocs.org.br/portal/publicacoes/rbcs_00_10/rbcs10_02.htm>. 2 ago. 2016.

Verissimo, Erico. Diário de criação de Incidente em Antares, em agenda do ano de 1970, com anotações sobre o romance e registro do andamento da escrita nos Estados Unidos. Documento do Acervo Literário de Erico Verissimo ALEV 04b0062-1970.

Esboços de Incidente em Antares, em pasta incluindo desenhos e rascunhos. Documento do Acervo Literário de Erico Verissimo ALEV 04f0083-1970.

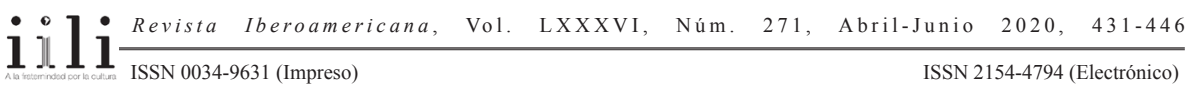


Incidente em Antares. 1971. São Paulo: Companhia das Letras, 2005.

Notas para A hora do sétimo anjo $e$ Solo de clarineta, em agenda do ano de 1970, com resumos e citações de obras existencialistas e socialistas, bem como roteiros, planos, esquemas e lembretes. Documento do Acervo Literário de Erico Verissimo ALEV 04a0029-1970.

Palavras-chave: Erico Verissimo; ditadura; alegoria

Recebido: $\quad 6$ novembro 2016

Aprovado: $\quad 15$ maio 2017 